\title{
Planktothrix rubescens' seasonal dynamics and vertical distribution in Lake Pusiano (North Italy)
}

\author{
Elena LEGNANI*, Diego COPETTI, Alessandro OGGIONI ${ }^{1)}$, Gianni TARTARI, Maria Teresa PALUMBO and \\ Giuseppe MORABITO ${ }^{1)}$
}

CNR - Water Research Institute, 20047 Località Occhiate, Brugherio, Italy

${ }^{1)} \mathrm{CNR}$ - Institute for the Ecosystem Study, Largo Tonolli 50, 28922 Verbania Pallanza, Italy

*e-mail corresponding author: legnani@irsa.cnr.it

\begin{abstract}
The limnological evolution of Lake Pusiano followed, starting 1970s, an increasing eutrophication process, attaining the maximum trophic level at the mid 1980s, when the lake reached an hypertrophic condition (around $200 \mu \mathrm{g} P l^{-1}$ at winter overturn). Between mid 1980s and the beginning of this century, the phosphorus concentrations continuously decreased, until reaching TP values close to $60 \mu \mathrm{g} P l^{-1}$. Despite this improvement in trophic conditions, since 1994 the cyanobacteria contribution increased: noticeable was a very intense bloom of Planktothrix rubescens, occurred during autumn 2001. The following year, when we carried out this research, this filamentous cyanobacterium strongly dominated the phytoplankton population for the whole seasonal cycle. However, after an intense flood occurred in November the P. rubescens population decreased again. This paper aims at describing the seasonal dynamics of the cyanobacterium P. rubescens in Lake Pusiano (North Italy) during year 2002, pointing out the environmental factors which favoured its large dominance during the whole seasonal cycle: particular attention will be paid to the role played by the physical factors in promoting the growth of P. rubescens, despite the nutrient reduction. Our experimental evidences suggest the involment of mechanisms already observed in other European lakes, such as the establishment of a metalimnetic niche. Moreover, our data point out a high sensitivity of this environment to the changes of the hydrological regime, which probably affect the seasonal phytoplankton dynamics.
\end{abstract}

Key words: Planktothrix rubescens, seasonal dynamics, Lake Pusiano

\section{INTRODUCTION}

Planktothrix rubescens is a cold water stenotherm species largely distributed in middle European (Reynolds 1984) and Southern sub-alpine lakes (Garibaldi et al. 2000).

During summer stratification it is usually located within the metalimnion (Konopka 1980; Reynolds 1984; Schreurs 1992; Feuillade 1994; Chorus \& Bartram 1999) where it is able to perform an active photosynthetic activity (Micheletti et al. 1998). In fact, due to the presence of an efficient accessory pigments apparatus (constituted by phycobiline and phycoerythrin proteins) this filamentous cyanobacterium is able to intercept the whole spectrum $(400-700 \mathrm{~nm})$ of the incoming Photosynthetic Active Radiation (PAR) and to perform active photosynthesis at very low values of irradiance (Reynolds 1997; Chorus \& Bartram 1999). The efficiency in PAR interception is enhanced by the high surface/volume ratio of the filamentous shape (Reynolds 1997). For these reasons the portion of water column below the $P$. rubescens peak is characterized by an intense screening of the incoming solar radiation which could inhibit the growth of other algae (Feuillade 1994). On the other side, this species is photoinhibited in conditions of high irradiance (Chorus \& Bartram 1999). It usually grows in water column where the
$\mathrm{Z}_{\mathrm{eu}} / \mathrm{Z}_{\text {mix }}$ ratio is close to 0.7-1.2 (Schreurs 1992) at depth where the penetrating PAR is around $1-5 \%$ of the surface values (Chorus \& Bartram 1999).

During the mixing period $P$. rubescens is spread within the entire water column but it is usually more concentrated in the upper part of the euphotic zone (Schmitt \& Olive 1980). During summer stratification the metalimnetic position is maintained by performing a relatively slow (around 0.1-0.8 $\mathrm{m} \mathrm{d}^{-1}$ ) buoyancy regulation (Reynolds 1984; Walsby et al. 2001). Buoyancy is allowed by the production of gas vesicles which is higher when the photosynthetic activity is low, on the contrary when primary production is higher, more hydrocarbons are stored, the density of the cells increases and the filaments become less buoyant (Kromkamp \& Walsby 1990). Vertical migration can be stimulated by both light intensity (Reynolds 1984) and nutrients distribution (Walsby \& Klemer 1974; Klemer 1976).

A statistical approach applied to 80 Dutch shallow lakes suggested that $P$. rubescens usually dominates environment with reactive phosphorus $\left(\mathrm{P}_{-} \mathrm{PO}_{4}\right)$ concentrations ranging between 0 and $10 \mu \mathrm{g} \mathrm{P}^{-1}$ (Schreurs 1992). Laboratory data suggest that in condition of $\mathrm{P}_{-} \mathrm{PO}_{4}$ limitation, $P$. rubescens is able to utilize organic forms of phosphorus due to the presence of alkaline phosphatase (Feuillade 1994). 


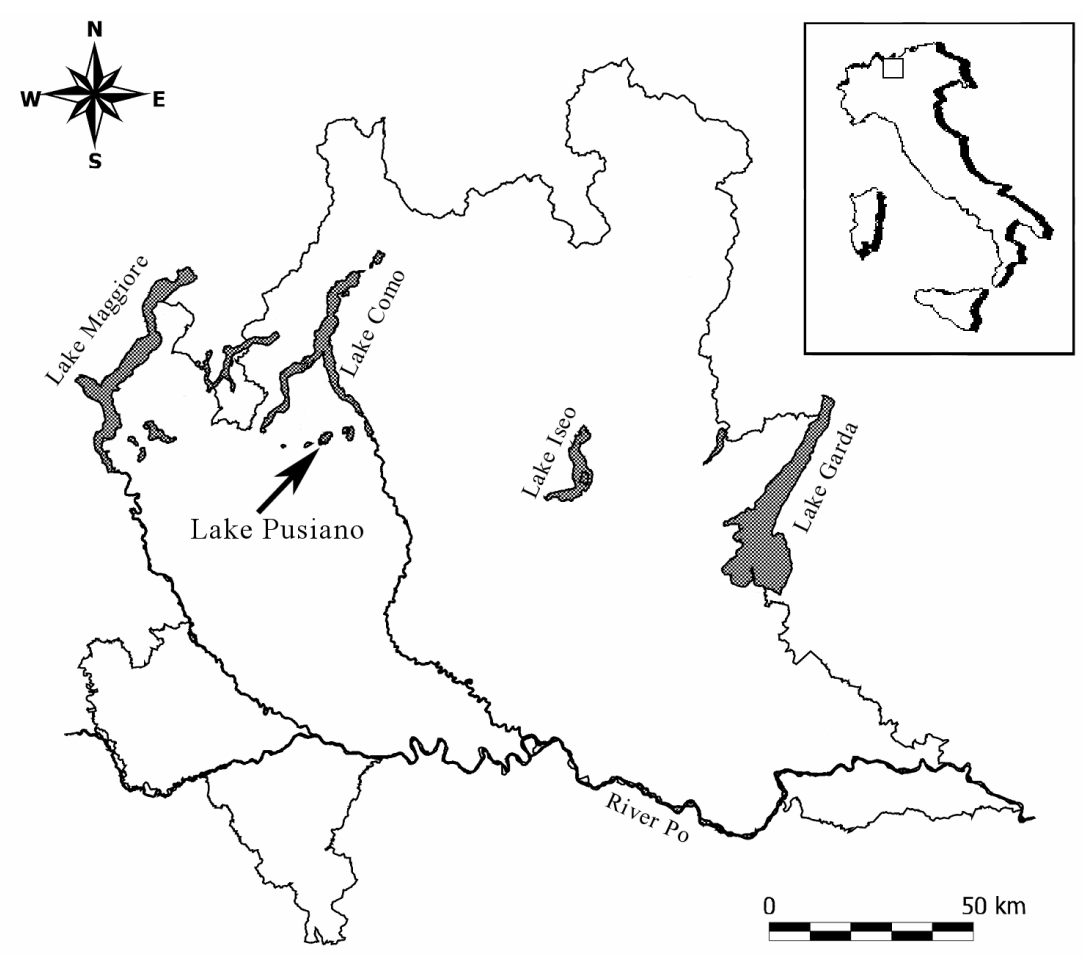

Fig. 1. Lake Pusiano location.

Tab. 1. Main morphometric features of Lake Pusiano and catchment area (GIS elaborations are based on CTR map, scale 1:10000, developed by Lombardy Regional Government: see reference under the name Regione Lombardia).

\begin{tabular}{lccl}
\hline Variable & Value & Unit & Reference \\
\hline Geographic coordinates & Long 521107 & UTM & Calculated data \\
& Lat 5072268 & 1950 & \\
Mean level lake's altitude & 259.7 & $\mathrm{~m}$ & GIS elaboration from CTR 1994 \\
Lake's perimeter & 12.6 & $\mathrm{~km}$ & GIS elaboration from CTR 1994 \\
Lake's area & 5.26 & $\mathrm{~km}^{2}$ & GIS elaboration from CTR 1994 \\
Volume & 69.2 & $\mathrm{~m}^{3} 10^{6}$ & Gaggino \& Cappelletti 1984 \\
Maximum depth & 24.3 & $\mathrm{~m}$ & Gaggino \& Cappelletti 1984 \\
Mean depth & 13.2 & $\mathrm{~m}$ & Calculated data \\
Maximum length & 3.8 & $\mathrm{~km}$ & GIS elaboration from CTR 1994 \\
Maximum width & 2.6 & $\mathrm{~km}$ & GIS elaboration from CTR 1994 \\
Sinuosity index & 1.44 & & Calculated data \\
Total catchment's area & 96.4 & $\mathrm{~km}$ & GIS elaboration from CTR 1994 \\
Maximum catchment's altitude & 1453 & $\mathrm{~m} \mathrm{a.s.1.}$ & Gaggino \& Cappelletti 1984 \\
Catchment's perimeter & 12.6 & $\mathrm{~km}$ & GIS elaboration from CTR 1994 \\
\hline
\end{tabular}

Like other cyanobacterial species, some clones of $P$. rubescens are able to produce microcystins (Chorus \& Bartram 1999) one of the most dangerous class of hepatotoxins currently known (Ade \& Funari 2000). The production of toxins has been interpreted as a defence strategy against the zooplankton, which usually avoids grazing the filaments of this species (see for an extensive review Kurmayer \& Jeüttner 1999). Moreover, the filamentous shape, difficult to handle by the alimentary apparatus of the herbivorous zooplankton, enhances the defence against grazing (Webster \& Peters 1978). Furthermore, many authors described the capability of toxic cyanobacteria to inhibit the growth of other algal species during massive blooms (see for example Sukenik et al. 2002).

The present study aims to describe the seasonal dynamics of $P$. rubescens in Lake Pusiano (North Italy) during 2002, pointing out the ecological factors which favoured its large dominance during the whole season.

\subsection{Study site and historical factors}

Lake Pusiano is an inter-morainic lake, located between the two branches of Lake Como (Fig. 1). It is a mid-size natural lake (volume $=69.210^{6} \mathrm{~m}^{3}$ ) with surface area of $5.26 \mathrm{~km}^{2}$ and mean depth of around $14 \mathrm{~m}$ (Tab. 1). 
More than one hundred scientific papers (Tartari et al. 2000) deal with Lake Pusiano, one of the most studied among Italian lakes. Seven major studies depict its limnological evolution (Vollenweider 1965; Bonomi et al. 1967; Gerletti \& Marchetti 1977; de Bernardi et al. 1985; Chiaudani \& Premazzi 1992; Quattrin et al. 1998; Tartari et al. 2000).

Lake Pusiano has been classified as a phosphorus limited environment considering the N/P mass ratio $>15$ (Chiaudani \& Vighi 1974; Redfield 1934). The TP concentrations during winter overturn increased in this environment between $1973\left(86 \mu \mathrm{g} \mathrm{P} \mathrm{l}^{-1}\right)$ and 1984 (198 $\mu \mathrm{g} \mathrm{P}^{-1}$ ), when the lake reached an hypertrophic condition (OECD 1982). Since the middle of 1980s the TP concentration continuously decreased until reaching a stable value around $60 \mu \mathrm{g} \mathrm{P}^{-1}$ at the beginning of this century. Two main interventions were responsible for the phosphorus reduction in Lake Pusiano: the prohibition, by the Italian legislation, in using polyphosphate in the detergents (Marchetti 1987) and the building of a sewage treatment plant within the catchment (Quattrin et al. 1998). Nitrogen did not follow the same trend: in the period 1973-2003 the total nitrogen concentrations ranged between 1.90 and 2.33 $\mathrm{mg} \mathrm{N} \mathrm{l}^{-1}$, due to the different origin of this chemical species, mainly coming from wet and dry atmospheric depositions and only in minor part from urban wastewaters and agricultural practices. Studies on the chemistry of atmospheric deposition in the pre-alpine zone, showed that this source is responsible for nitrogen loads among the highest in Northern Italy and that this amount remained almost constant during the last decade (Balestrini et al. 2000).

Transparency followed a similar trend of the TP concentrations. In 1972 the Secchi disk (SD) depths were typical of a productive environment with a maximum value of $3.6 \mathrm{~m}$ in January. At 1984 winter overturn the transparency decreased to $1.25 \mathrm{~m}$, whereas in 1995 the partial recovery of the lake ecosystem is confirmed by a winter overturn transparency higher than $8 \mathrm{~m}$.

Between 1973 and 1994 four limnological studies described the seasonal phytoplankton succession in Lake Pusiano (Gerletti \& Marchetti 1977; Scaglia 1986; Chiaudani \& Premazzi 1992; Quattrin et al. 1998). Information related to winter overturn and summer stratification only, are available from Bonomi et al. (1967) and de Bernardi et al. (1985). Because of the irregularity in phytoplankton studies it is difficult to recognize a clear evolution of the algal assemblages in Lake Pusiano. The following is a tentative to outline the meaningful steps of the inter-annual succession during the last three decades.

In 1967 the contribution of cyanobacteria in Lake Pusiano was very low. Among the twenty species described by Bonomi et al. (1967) only two belonged to cyanobacteria (Gomphosphaeria aponina and
Merismopedia tenuissima). The limnological surveys conducted in 1972-1973 (Gerletti \& Marchetti 1977), 1985-1986 (Scaglia 1986) and 1987-1989 (Chiaudani \& Premazzi 1992) confirmed the same situation. Thereafter, the phytoplankton structure suddenly shifted towards the cyanobacteria domination. In 1994-1995 more than 25 species of Cyanoprokaryota were detected. During summer the phytoplankton was dominated by three Chroococcales (Aphanothece sp., Microcystis sp. and Merismopedia tenuissima) whose total density was greater than 150,000 cells $\mathrm{ml}^{-1}$. Finally after few occurrences of reddish algal blooms, ascribed to $P$. rubescens, during the 2001 autumn a very intense bloom of $P$. rubescens took place. The following year this cyanobacterium strongly dominated the Lake Pusiano ecosystem for the whole season. Between 2002 and 2003, after an intense autumnal flood, a sudden shift between cyanobacteria and chlorophyte has been detected.

This historical picture points out a consistent increase of the cyanobacteria between 1994 and 2002, in concomitance with a significant improvement of the trophic conditions. However, as the most recent records show, exceptional hydrological inputs can deeply affect the hydrological regime of the lake, playing as a controlling factor of the phytoplankton dynamics.

\section{MATERIAL AND METHODS}

During the 2002 limnological survey, 16 samplings were conducted in Lake Pusiano, at the point of maximum depth. The frequency of the sampling was monthly in absence of stable stratification and fortnightly during summer stratification (June-September).

Transparency was measured by Secchi disk (SD). Conductivity (at $20^{\circ} \mathrm{C}$ ), $\mathrm{pH}$, temperature, chlorophyll- $a$, dissolved oxygen and percentage of oxygen saturation were measured in real time during each sampling using two multiparametric probes (Idronaut Ocean Seven Mod. 401 e Ocean Seven Mod. 401 equipped with a Sea Tech fluorometer). During four seasonal samplings (April, August, October and December) the underwater PAR was measured by a Li-Cor 192-SA quantum flat sensor, allowing a direct estimation of the euphotic zone depth and an evaluation of the relationship between Secchi depth and euphotic zone depth.

This relationship, reported below, was then used to calculate Zeu when direct measurements of PAR were not available.

$$
Z_{\text {eu }}=3.042 \times S D^{0.722}(r=0.966 ; n=4 ; p<0.01)
$$

Although this regression model was obtained from four points only, it could be used to obtain a reliable estimation of $Z_{\mathrm{eu}}$ in our range $(1.6-5.5 \mathrm{~m})$ of Secchi depths.

A thermistor chain with 13 temperature sensors (VEMCO - Minilog8-TR, $-5-+35^{\circ} \mathrm{C}$ ) and one pressure sensor (VEMCO - Minilog8-TDR) has been settled at 
the deepest station. The data were recorded every 15 minutes.

Water samples for chemical analysis were collected by a Van Dorn bottle at seven different sampling depths $(0.5,2.5,5,7.5,10,15,22.5 \mathrm{~m})$. The following variables were measured: total nitrogen, total phosphorous and reactive phosphorus (Valderrama 1977, 1981); main hydrochemical (alkalinity, nitrate, sulphate, chloride, ammonium, calcium, magnesium, sodium, potassium) variables (A.P.H.A. AW.W.A W.E.F. 1995; Camusso \& Polesello 2000a, b).

Phytoplankton samples, integrated on the water column, were collected monthly and fixed with Lugol's solution. Specific identification and counting were carried out at the inverted microscope, following the criteria reported in the monographs of the Series "Das Phytoplankton des Suesswassers", established by Huber-Pestalozzi and in Starmach (1966, 1974, 1980), Geitler (1932), Krammer \& Lange-Bertalot (1986, 1988, 1991a, b, 2000), Ettl (1978), Frère Irénee-Marie (1938), Komarek \& Anagnostidis (1999). Biovolume was estimated by geometrical approximations according to Sicko-Goad et al. (1977), Trevisan (1978), and Rott (1981). Phytoplankton data have been analysed by cluster analysis, carried out on a distance matrix, obtained from the calculation of the Bray-Curtis similarity index (Bray \& Curtis 1957).

Phytoplankton biodiversity was calculated from abundance data, using the Shannon-Wiener index (Shannon \& Weaver 1949) and 10 as the base log.

Samples for the analysis of the marker pigments were collected monthly at five depths, selected according to the vertical distribution of chlorophyll- $a$ (measured by fluorometric probe, see above). 700 to $3500 \mathrm{ml}$ of water were filtered onto Whatman GF/F filters and the filters were frozen at $-10{ }^{\circ} \mathrm{C}$ until analysed. Frozen filters were placed in $9 \mathrm{ml}$ of $90 \%$ acetone, grinded with Ultra-Turrax T25 (10000 rpm for $1 \mathrm{~min})$ and extracted in darkness overnight a $4{ }^{\circ} \mathrm{C}$. Pigment extracts were centrifuged and a volume of $100 \mu 1$ of filtered mixture was injected into a Beckman HPLC system equipped with a reverse phase $\mathrm{C} 18$ column (Jeffrey et al. 1997).

Data on the concentration of specific marker pigments allowed to estimate the biomass of $P$. rubescens, using a multiple linear regression model with breakpoint. The main advantage of this technique is that the model takes into account that the nature of the relationship between one or more independent variables and the dependent variable changes over the range of the independent variables, giving different values of the curve parameters (slope and intercept). In our case the relationship between the biovolume of a single algal class and the specific pigments changes below a certain pigment concentration (indicated as breakpoint). The pigments to be included in the equation have been chosen according to the typical pigment composition of
P. rubescens: chlorophyll- $a$ and the carotenoids $\beta, \beta-$ Carotene, Echinenone, Lutein, Lycopen and Oscillaxanthin (Feuillade \& Davies 1994). Lacking discrete phytoplankton samplings, these estimations were successfully utilized to describe the vertical distribution of $P$. rubescens.

Primary productivity was measured once per season (April 22 $2^{\text {nd }}$; August 20 $0^{\text {th }}$; October $15^{\text {th }}$ and December $10^{\text {th }}$ ), by the ${ }^{14} \mathrm{C}$ technique (Danish-StandardAssociation 1982). Two replicate bottles (each labelled with $5 \mu \mathrm{Ci}$ of radioactive $\mathrm{NaH}^{14} \mathrm{CO}_{3}$ ) were incubated in situ with a multiple holder at five depths corresponding to $100 \%, 50 \%, 25 \%, 10 \%$ and $1 \%$ of the subsurface PAR. The incubation were usually kept in situ for $4 \mathrm{~h}$ around noon. After the incubation, $30 \mathrm{ml}$ of the sample were filtered through Nucleopore PC filters $(0.2 \mu \mathrm{m}$ pore size); the filters were transferred to LS vials, acidified and, after $1 \mathrm{~h}$, placed in the liquid scintillation counter (Beckman LS 6000). Counting efficiency was automatically determinated by the use of a ${ }^{14} \mathrm{C}$ standard. The daily productivity was calculated according to Platt (1971).

The Algal Growth Potential (AGP), as a sensitive method to detect changes in nutrient bioavailability, was measured on lake water samples collected in June 2003 from one sampling site at 5 different depths $(1,3,5.5$, $7.5,12.5 \mathrm{~m}$ ), selected to be representative of the termocline profile. The algal assay was performed according to the basic EPA methods (1978). The green alga Selenastrum capricornutum cultured in P-limited medium was used as test organism. P-depleted cells $(8000$ cell $\mathrm{ml}^{-1}$ ) were used to inoculate the $0.45 \mu \mathrm{m}$ filtered lake water. Triplicate samples were incubated under controlled conditions until the maximum standing crop was reached in all samples. The algal growth was daily monitored using an electronic particle counter (Coulter Counter ZBI) to determine the maximum algal biomass supported by each sample. The measured values of cell density were expressed as $\mathrm{mg}^{-1}$ dry weight of algal biomass.

\section{RESULTS}

\subsection{Physical and chemical features of Lake Pusiano}

Figure 2 reports the thermal structure of Lake Pusiano between February $7^{\text {th }} 2002$ and March $4^{\text {th }}$ 2003. Until April $24^{\text {th }}$, the data are related to monthly sampling, whereas, after this date, to a thermistor chain located at the point of maximum depth. The isotherm plot has been obtained interpolating by kriging the temperature data recorded at 11:00 AM of each day. In February the temperature was homogeneously distributed along the water column at around $4.3{ }^{\circ} \mathrm{C}$. After an incipient stratification in March, a stable metalimnion can be identified between April and November. In summertime the thermocline is located at around 7-8 $\mathrm{m}$ depth, whereas in autumn the thickness of the mixed layer gradually increased and the thermocline 


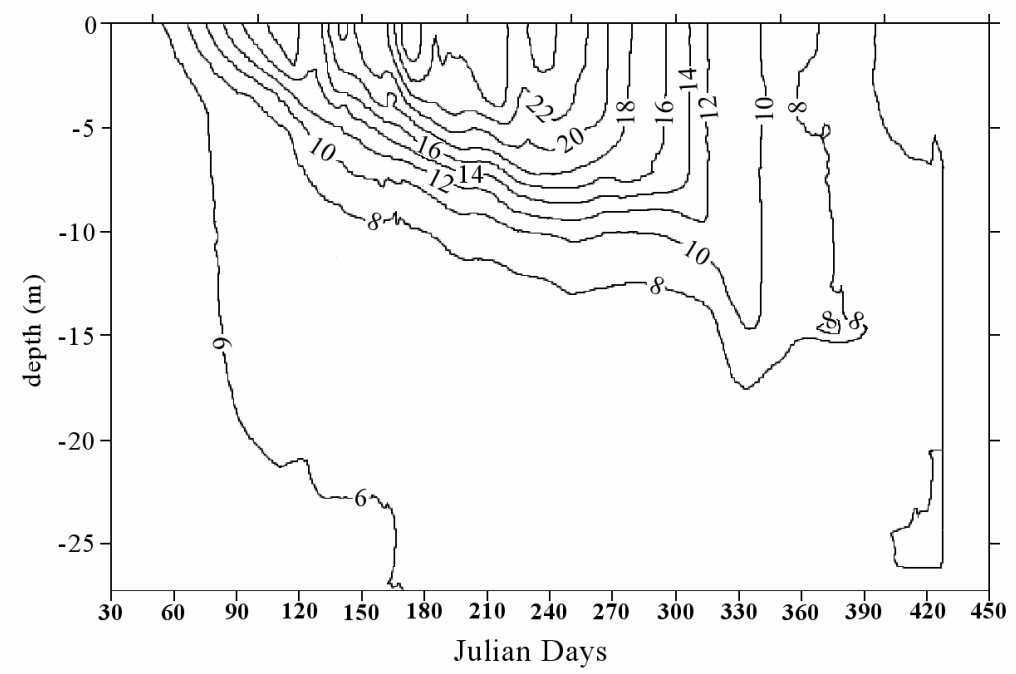

Fig. 2. Lake Pusiano thermal structure between February 2002 and March 2003. Interpolation obtained with Surfer ${ }^{\circledR}$ Golden Software.

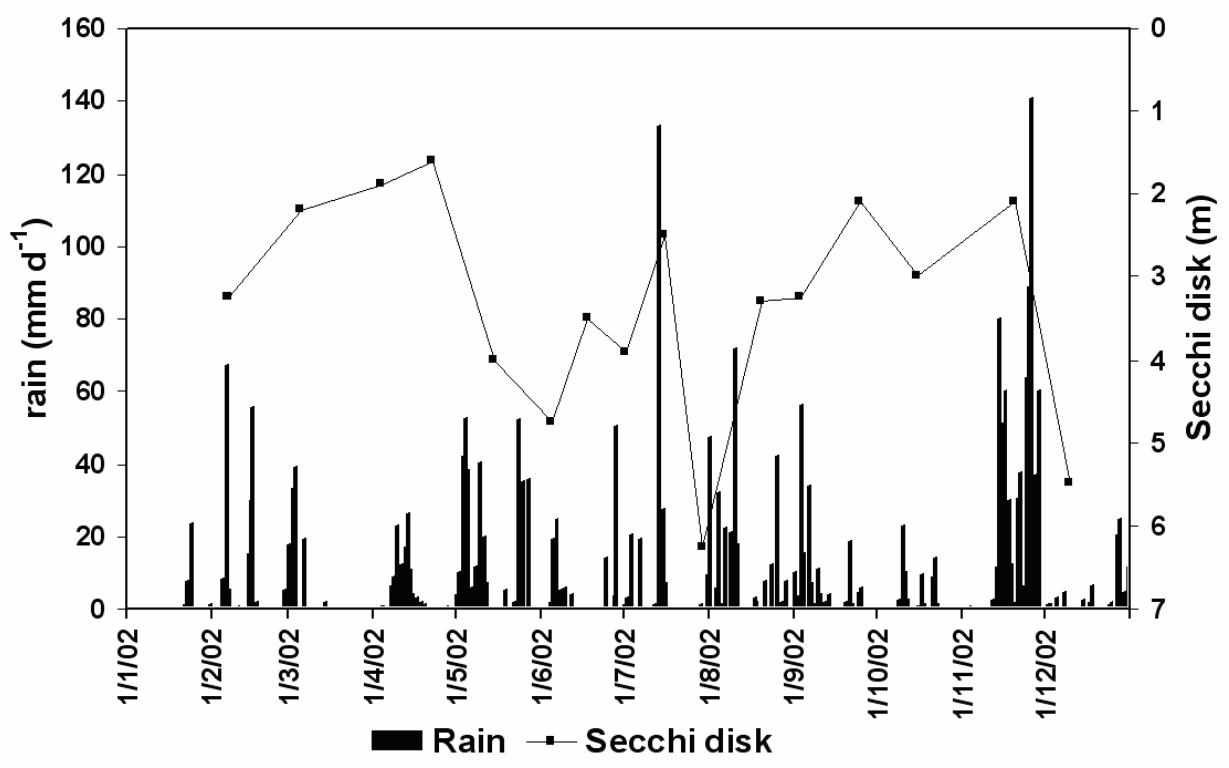

Fig. 3. Trend of the transparency as depth of Secchi disk disappearance and $\mathrm{mm} \mathrm{d}^{-1}$ of rainfall during 2002.

dropped down until its disappearance at the time of mixing. Figure 2 also shows the very short period (less than 10 days) of complete overturn, occurred between January and February 2003.

Figure 3 shows the seasonal trend of transparency. The minimum value $(3.2 \mathrm{~m})$ was measured in April when the maximum $P$. rubescens peak occurred, whereas the maximum value was detected in July (6.3 m) after an intense rainy period (Fig. 3) and when an abrupt crash of the $P$. rubescens population took place.

The chemical features of the water of Lake Pusiano at both 2002 winter overturn and maximum stratification are reported in table 2. The ionic spectrum is typical of a karst catchment (Salerno et al. 2004) with high concentration of calcium and magnesium. During winter overturn the total soluble ions $\left(7 \mathrm{meq} \mathrm{l}^{-1}\right)$ determined an homogeneous specific conductivity within the water column of $288 \mu \mathrm{S} \mathrm{cm}^{-1}$ at $20{ }^{\circ} \mathrm{C}$. Due to the high productivity and the consequent modification of carbonate equilibrium, in summer season Lake Pusiano waters showed a consistent calcium carbonate precipitation within the epilimnion, which led to the maximum reduction in calcium concentrations, corresponding to about $27.8 \%$ less than the content at winter overturn. On the bottom the anoxic condition, which were detected between May and October, determined the sulphate sulphide reduction. On the contrary the concentration of the conservative species, such as chloride and potassium, were mainly influenced by hydrological regime. 
Tab. 2. Main hydrochemical features of Lake Pusiano during winter overturn and summer maximum stratification. Summer values are weighted averages in the three column layers indicated.

\begin{tabular}{llcccc}
\hline Variable & Unit & $\begin{array}{c}\text { Mixing } \\
(07 / 02 / 02)\end{array}$ & \multicolumn{3}{c}{$\begin{array}{c}\text { Stratification } \\
(20 / 08 / 02)\end{array}$} \\
\cline { 3 - 5 } & & & $\begin{array}{c}\text { Epilimnion } \\
(0-5 \mathrm{~m})\end{array}$ & $\begin{array}{c}\text { Metalimnion } \\
(5-12 \mathrm{~m})\end{array}$ & $\begin{array}{c}\text { Hypolimnion } \\
(>12 \mathrm{~m})\end{array}$ \\
\hline Temperature & ${ }^{\circ} \mathrm{C}$ & 5.0 & 22.2 & 12.9 & 6.9 \\
Conductivity & $\mu \mathrm{S} \mathrm{cm}^{-1} 20^{\circ} \mathrm{C}$ & 288 & 242 & 249 & 305 \\
pH & & 7.95 & 8.38 & 8.14 & 7.60 \\
Total alkalinity & $\mathrm{meq} \mathrm{1}^{-1}$ & 3.25 & 2.15 & 2.37 & 3.05 \\
Sulphate & $\mathrm{meq} \mathrm{1}^{-1}$ & 11.0 & 10.1 & 9.9 & 9.6 \\
Chloride & $\mathrm{mg} \mathrm{l}^{-1}$ & 6.0 & 4.9 & 5.2 & 6.4 \\
Nitrate & $\mathrm{mg} \mathrm{N}^{-1}$ & 0.3 & 0.6 & 0.5 & 0.1 \\
Ammonium & $\mu \mathrm{g} \mathrm{N} \mathrm{l}^{-1}$ & 394 & 30 & 98 & 617 \\
Calcium & $\mathrm{mg} \mathrm{l}^{-1}$ & 47.5 & 34.3 & 38.7 & 49.3 \\
Magnesium & $\mathrm{mg} \mathrm{l}^{-1}$ & 8.6 & 7.9 & 8.0 & 8.4 \\
Sodium & $\mathrm{mg} \mathrm{l}^{-1}$ & 4.7 & 4.1 & 4.1 & 4.7 \\
Potassium & $\mathrm{mg} \mathrm{l}^{-1}$ & 1.4 & 1.2 & 1.2 & 1.4 \\
Total P & $\mu \mathrm{g} \mathrm{P} \mathrm{l}^{-1}$ & 63 & 8 & 16 & 75 \\
Reactive P & $\mu \mathrm{g} \mathrm{P} \mathrm{l}^{-1}$ & 31 & 1 & 1 & 34 \\
Total N & $\mathrm{mg} \mathrm{N}^{-1}$ & 1.1 & 1.1 & 1.0 & 1.2 \\
\hline
\end{tabular}
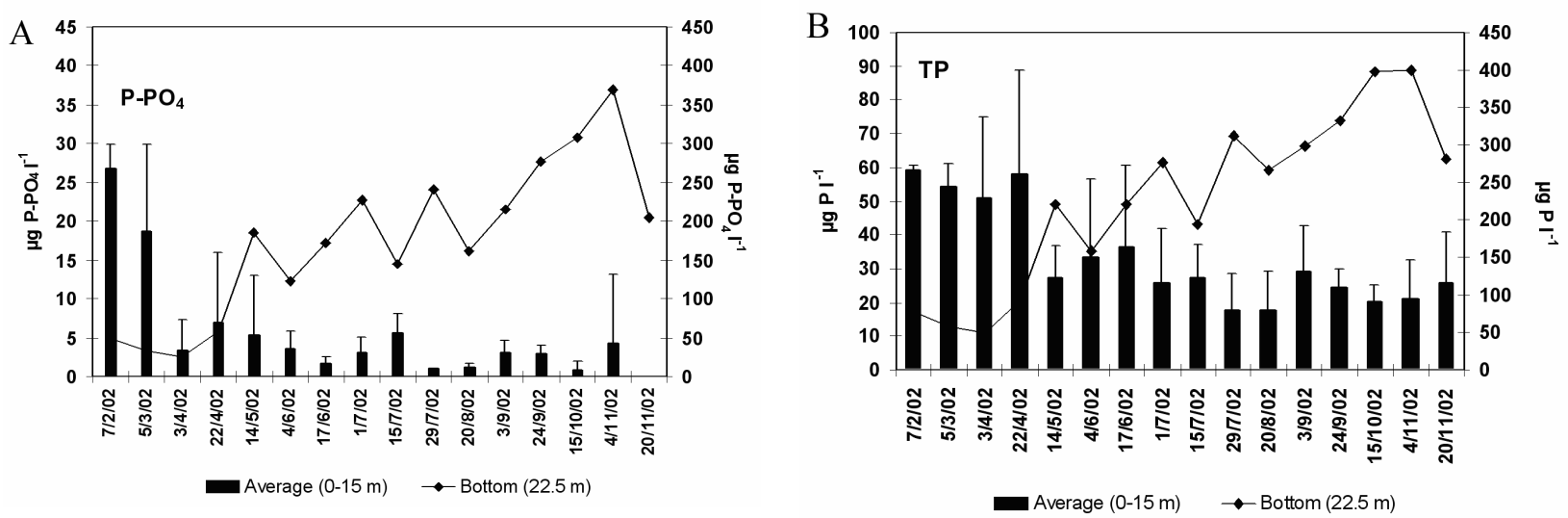

Fig. 4. Trend of the $\mathrm{P}_{-} \mathrm{PO}_{4}(\mathbf{A})$ and TP (B) concentrations as the average (left scale) between 0 and $15 \mathrm{~m}$ and on the bottom (right scale).

\subsection{Trophic conditions}

During winter circulation the TP and $\mathrm{P}_{-} \mathrm{PO}_{4}$ average concentrations were 63 and $31 \mu \mathrm{g} \mathrm{P} \mathrm{l^{-1 }}$ respectively (Tab. 2 and Fig. 4). With the establishment of the thermal stratification the $\mathrm{P}_{-} \mathrm{PO}_{4}$ epilimnetic concentrations were always below $7 \mu \mathrm{g} \mathrm{P}^{-1}$ and during some samples (July, August and October) below $2 \mu \mathrm{g} \mathrm{P} \mathrm{l}^{-1}$, indicating a strong limitation for the algal growth. The same trend has been followed by the TP which reached a minimum value around $10 \mu \mathrm{g} \mathrm{P}^{-1}$.

Conversely, during summer stratification an increase of bottom phosphorus concentrations (Tab. 2), due to both mineralization of the organic matter and release from the sediments, has been detected (Fig. 4). The highest values of both $\mathrm{P}_{-} \mathrm{PO}_{4}$ and TP concentrations at $22.5 \mathrm{~m}$ depth have been measured in November, when they reached 369 and $399 \mu \mathrm{g} \mathrm{P}^{-1}$ respectively.
During February 2002 TN showed an average value of $1.1 \mathrm{mg} \mathrm{N}^{-1}$ which remained almost constant between 0.5-15 $\mathrm{m}$ depth during the whole research period (Fig. 5).

An increase in nitrogen concentrations has been also found in the deepest layer (Tab. 2), with the highest concentrations measured in October at $22.5 \mathrm{~m}$, when the $\mathrm{TN}$ reached $3.46 \mathrm{mg} \mathrm{l}^{-1}$. On the basis of the nutrient cycles described above, phosphorus clearly appears as the nutrient limiting factor: its concentrations, in molar units, were around one order of magnitude lower than nitrogen $\left(\mathrm{N}=0.0786 \mathrm{mmol} \mathrm{l}^{-1} ; \mathrm{P}=0.00203 \mathrm{mmol} \mathrm{l}^{-1}\right.$ at winter overturn).

Summarizing, despite a global improvement of the trophic status, Lake Pusiano is still in eutrophic conditions, as underlined by the high phosphorus values during winter overturn and the low transparency at the beginning of the growing season. However, during the stratification period, the $\mathrm{P}_{-} \mathrm{PO}_{4}$ epilimnetic concentration probably decreases to limiting values. 


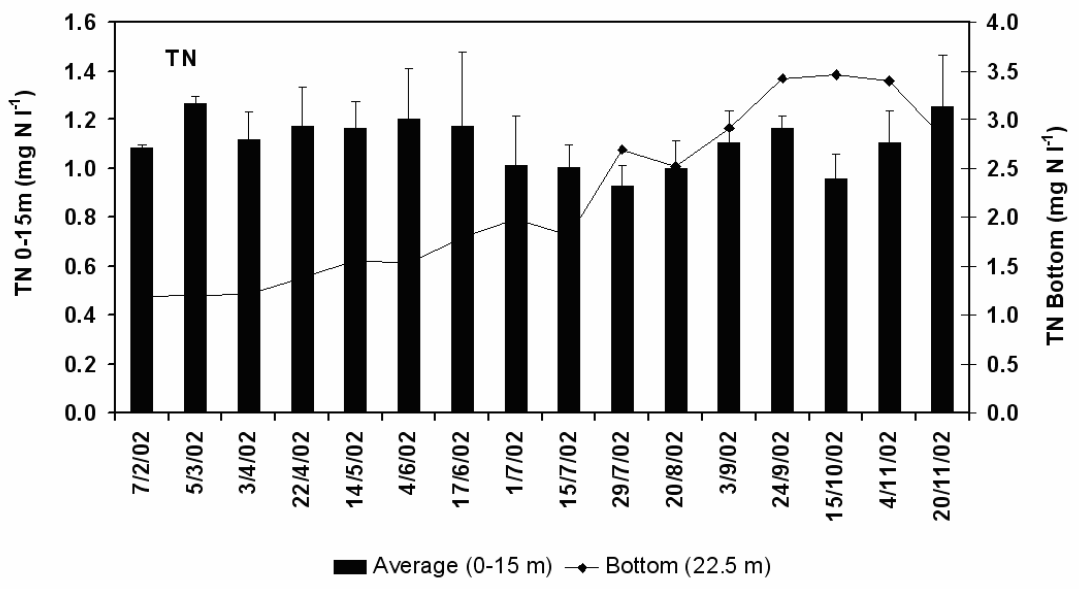

Fig. 5. Yearly TN concentrations evolution as average (left scale) between 0 and $15 \mathrm{~m}$ and on the bottom (right scale).

\subsection{Phytoplankton communities}

The spectrum of the meaningful species points out that a very low number of species contributed significantly to the phytoplankton composition. In fact among the 72 species recognized, just 10 contributed at least once during the year to build up the $90 \%$ of total density (Anabaena viguieri, Aphanizomenon flos-aquae, Aphanothece clathrata, Merismopedia tenuissima, Microcystis aeruginosa, Planktothrix rubescens, Pseudanabaena sp., Kathablepharis ovalis, Chrysochromulina sp. and Monoraphidium convolutum). Among these species $P$. rubescens exceeded the $90 \%$ of total density in spring and remained constantly over $60 \%$ until August, when Merismopedia tenuissima became dominant with $56 \%$ of contribution. The following month $P$. rubescens reached again percentages greater than $70 \%$.

In terms of biomass the contribution of the larger species is more evident, in particular Cryptomonas erosa, Dinobryon divergens, Fragilaria crotonensis, Asterionella formosa, Cyclotella ocellata and Gymnodinium spp. However, the role of P. rubescens as the key stone species during the whole season strongly appears even as biomass.

During the research period the phytoplankton succession was characterized by a strong dominance of $P$. rubescens. Figure 6 reports the phytoplankton succession, in terms of both density (cells $\mathrm{ml}^{-1}$ ) and biovolume $\left(\mathrm{mm}^{3} \mathrm{~m}^{-3}\right)$, of the main algal groups, as well as a focus on the cyanobacteria dominant species.

At the beginning of the growing season (between February and March) cyanobacteria were already the dominant algal group with a density exceeding 30000 cell $\mathrm{ml}^{-1}$ and a biovolume greater than $2600 \mathrm{~mm}^{3} \mathrm{~m}^{-3}$ (Fig. 6). The highest specific contribution within the cyanobateria was given by $P$. rubescens. During early spring a limited presence of Bacillariophyceae (Asterionella formosa and Cyclotella ocellata) was also recorded, with a density values around 1000 cells $\mathrm{ml}^{-1}$ and biovolume close to $1000 \mathrm{~mm}^{3} \mathrm{~m}^{-3}$. Other algal groups, such as Euglenophyceae (Euglena gracilis), Cryptophyceae (Cryptomonas erosa, Kathablepharis ovalis and Rhodomonas minuta), Chrysophyceae (Chrysochromulina sp. and Mallomonas sp.), Chlorophyta (Pandorina sp. and Eudorina sp.) and Dinophyceae (Gymnodinium sp.) were also found, although with very low values of biovolume and density.

Maximum values of $P$. rubescens biomass were reached in April $\left(3367 \mathrm{~mm}^{3} \mathrm{~m}^{-3}\right)$. After this peak $P$. rubescens population continuously decreased until August when it dropped down to a minimum biovolume of $644 \mathrm{~mm}^{3} \mathrm{~m}^{-3}$. At the same time (between July and August) a change in phytoplankton composition has been detected (Fig. 6). This change was mainly due to the contribution of small species such as Merismopedia tenuissima and Aphanothece clathrata, as suggested by the peak in cell density and the minimum in biovolume. Inside the cyanobacteria group, a noticeable increase of Aphanizomenon flos-aquae, Microcystis aeruginosa and Pseudanabaena sp. took place, increasing the phytoplankton biodiversity.

At the end of the summer, cyanobacteria increased again, mainly with $P$. rubescens, together with other species (e.g. Pseudanabaena sp., Aphanizomenon flosaquae). Bacillariophyceae were also important with Cyclotella ocellata. Finally, in November the total density reached its minimum value $\left(1555\right.$ cells ml$\left.^{-1}\right)$. All the groups decreased but Chlorophyta, which reached their maximum seasonal density (1439 cells ml ${ }^{-1}$ ), mainly due to the presence of Monoraphidium convolutum.

The trend of phytoplankton biodiversity during the research period is reported in figure 7A. The ShannonWiener index remained at relatively low values for most of the season. The minimum value $(0.17)$ was reached in April, in concomitance with the maximum peak of $P$. rubescens, whereas the maximum value of 1.48 occurred at the time of the minimum abundance of $P$. rubescens, corresponding to the change in specific composition above described. 

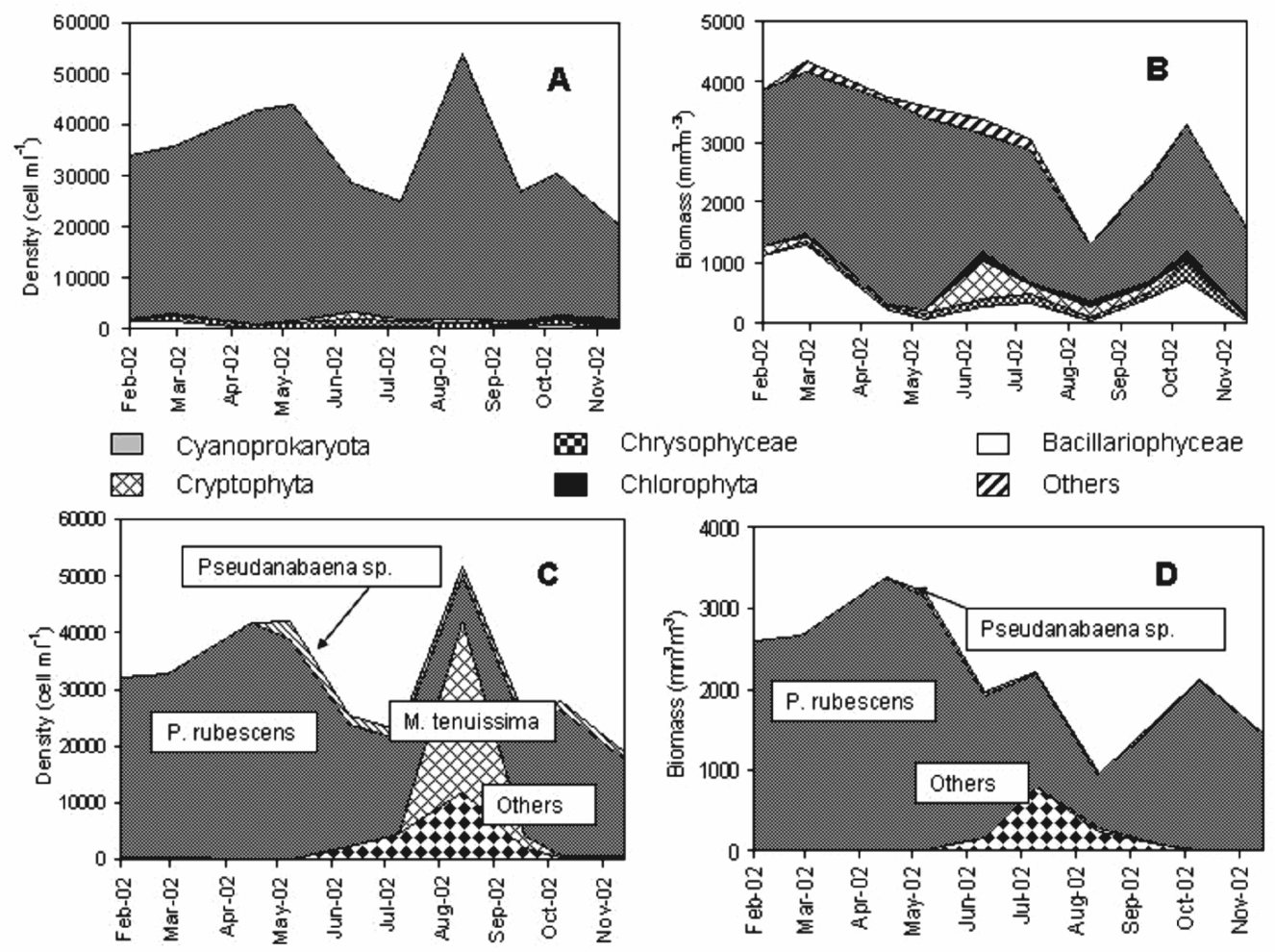

Fig. 6. Seasonal trends of density (cell ml ${ }^{-1}$; panel A) and biomass $\left(\mathrm{mm}^{3} \mathrm{~m}^{-3}\right.$; panel $\left.\mathbf{B}\right)$ of the main phytoplankton groups and of the most important blue-green species (panel $\mathbf{C}$, density; panel $\mathbf{D}$, biomass).
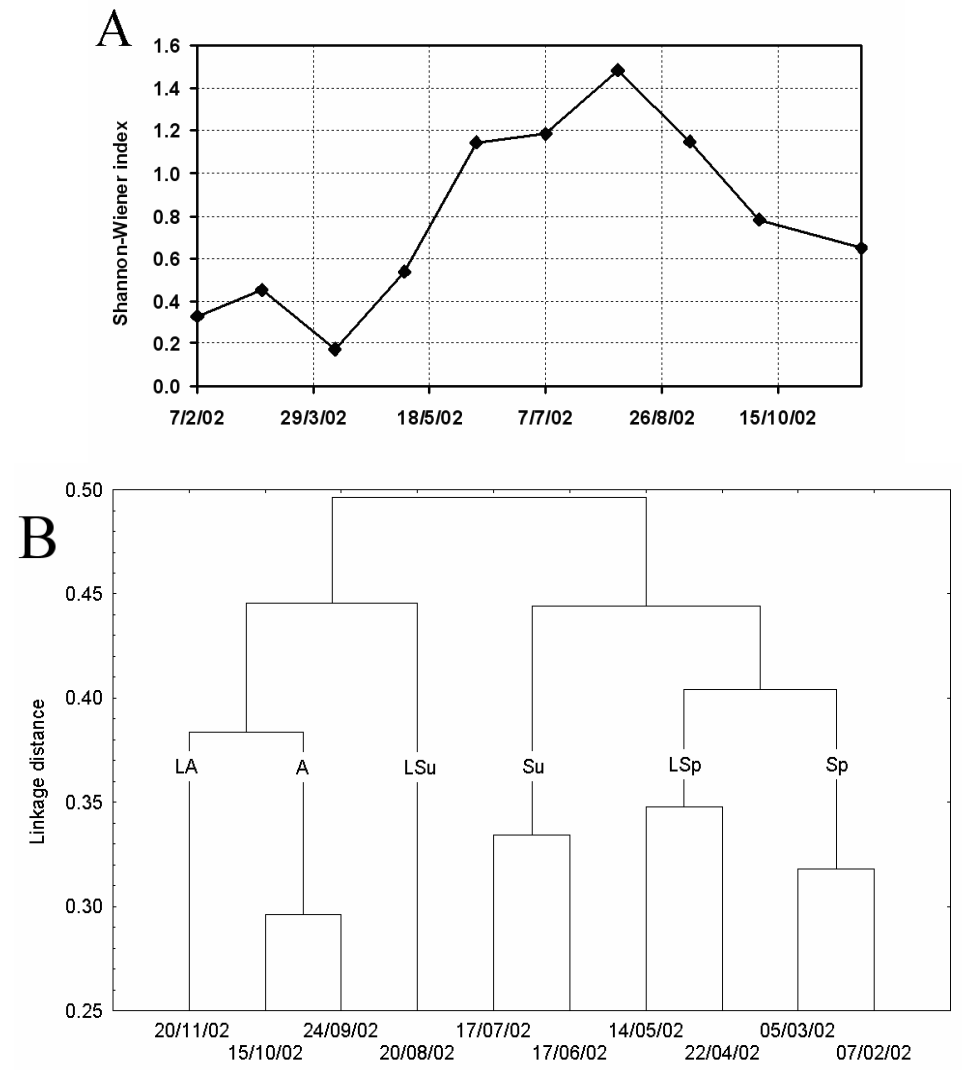

Fig. 7. Shannon index (A). Cluster analysis dendrogram (B) representing the distance between the different samples, sorted on the $x$ axis. The codes of the seasonal groups are reported in the text following the MMMDDYY scheme. 


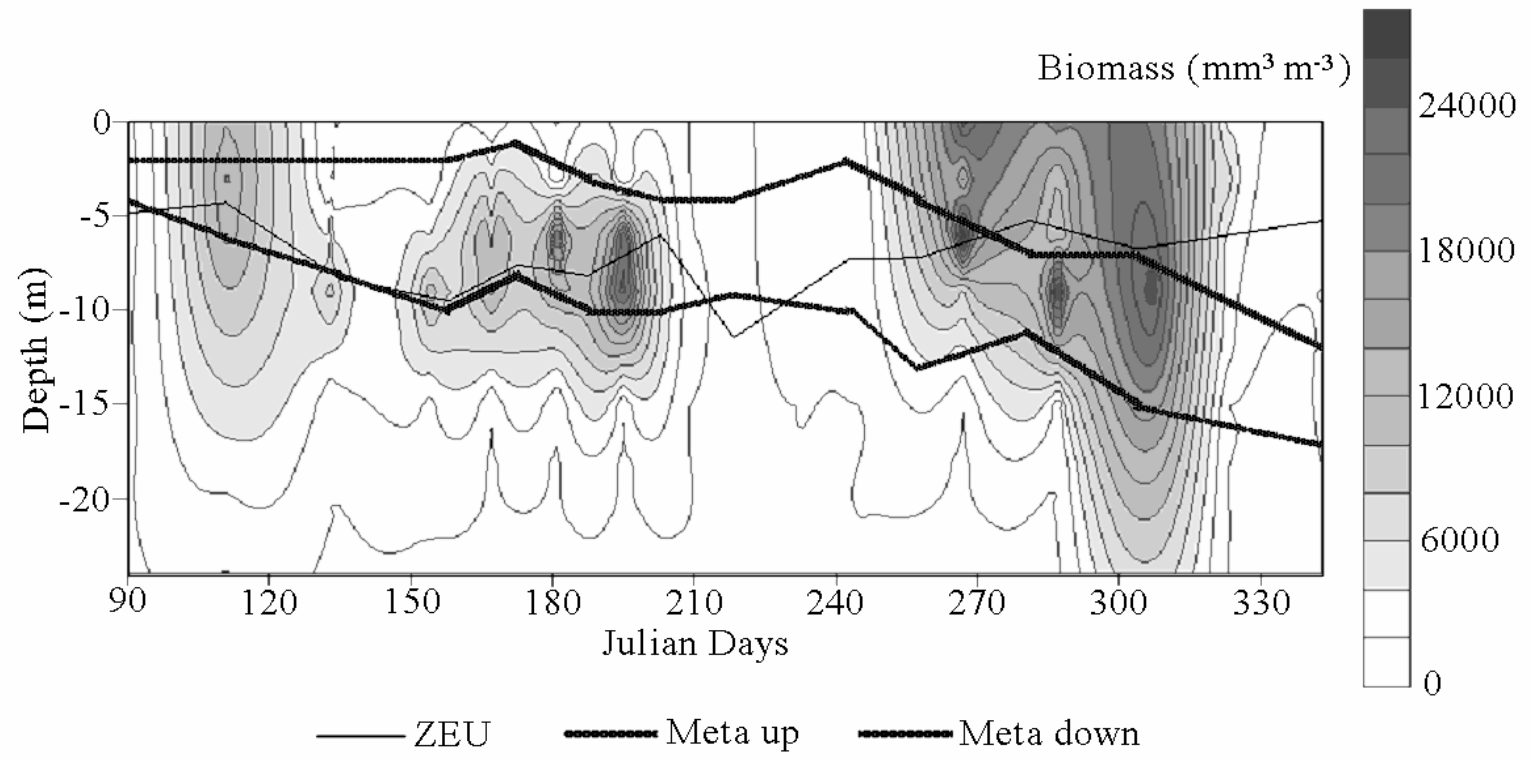

Fig 8. P. rubescens vertical distribution during 2002, estimated from the vertical distribution of its specific marker pigments. The pigment concentration has been converted into biomass as explained in the text. Meta up (upper thick line) and Meta down (lower thick line) indicates the position of two thermoclines, the upper one due the water inflow from Lambrone River.

The degree of similarity among the samples, quantified through the calculation of the Bray \& Curtis index (Bray \& Curtis 1957), has been graphically represented by means of a cluster analysis (Fig. 7B). Figure $7 \mathrm{~B}$ reports the dendrogram obtained with the abundance data: the use of the biomass gave almost the same sample clustering and the results are not reported here. The samples are separated into two main clusters, at 0.5 linkage distance: this clustering pattern probably mirrors the shift in the assemblage composition following the period of intense rainfall in July. At least three main aspects of the cluster analysis are noteworthy. As first, the high similarity among all the samples (low values of linkage distance), testifying the almost continuous dominance of a single species, Planktothrix rubescens.

As second, the high dissimilarity among the Lsu (Late Summer) sample and the others (Su, summer; A, autumn; LA, late autumn; Sp, spring; and LSp, late spring), clearly mirrors the decline of $P$. rubescens and the following shift in the specific composition. The third aspect is the inclusion, at a linkage distance of 0.44 , of the LSu sample into the autumnal cluster, due to the presence of a more diversified population inside the cyanobacteria group (see above).

The analysis of the marker pigments allowed reconstructing the vertical distribution of $P$. rubescens during the seasons: its metalimnetic stratification is very clear in figure 8 .

Between February and March the vertical displacement of $P$. rubescens followed the pattern described by Schmitt \& Olive (1980), with the trichomes distributed along the column but more concentrated in the upper euphotic zone. In these conditions the dominant species grew up until the end of April when it reached the maximum abundance. When the water column stratified, $P$. rubescens peaked within the metalimnion, where light climate was more suitable for growing.

The measurements of primary productivity demonstrated the high photsysnthetic capability of $P$. rubescens at low light intensities. Figure 9 reports a focus on April $22^{\text {th }}$ bloom. The peaks in P. rubescens biomass and chlorophyll- $a$ concentrations both occurred within the metalimnion, at depths close to the limit of the euphotic zone (Fig. 9A). The high values of primary productivity (Fig. 9B) at the same depths show that $P$. rubescens was actively growing.

An experiment on the trophic potentiality of the metalimnetic layer was conducted in July 2003. The Algal Growth Potential assay revealed sensitive enough to enable defining a clear profile of phosphorus bioavailability over the water column. Particularly, the lowest value $\left(0.1 \mathrm{mg} \mathrm{l}^{-1}\right.$ AGP) was measured in the epilimnetic layer ( 1 to $3 \mathrm{~m}$ depth) while the maxima (0.27 to $0.28 \mathrm{mg} \mathrm{l}^{-1}$ AGP) all over the hypolimnion (7.5 to $12.5 \mathrm{~m}$ depth), the maximum increase being found just in the metalimnetic layer (3 to $7.5 \mathrm{~m}$ depth), as shown in figure 10.

\section{DISCUSSION AND CONCLUSIONS}

As above reported, at the beginning of the growing season $P$. rubescens was already the dominant species within the phytoplankton population $(90 \%$ of the total density and $60 \%$ of the total biomass). This large contribution of $P$. rubescens is likely the residual of the previous autumnal bloom. 

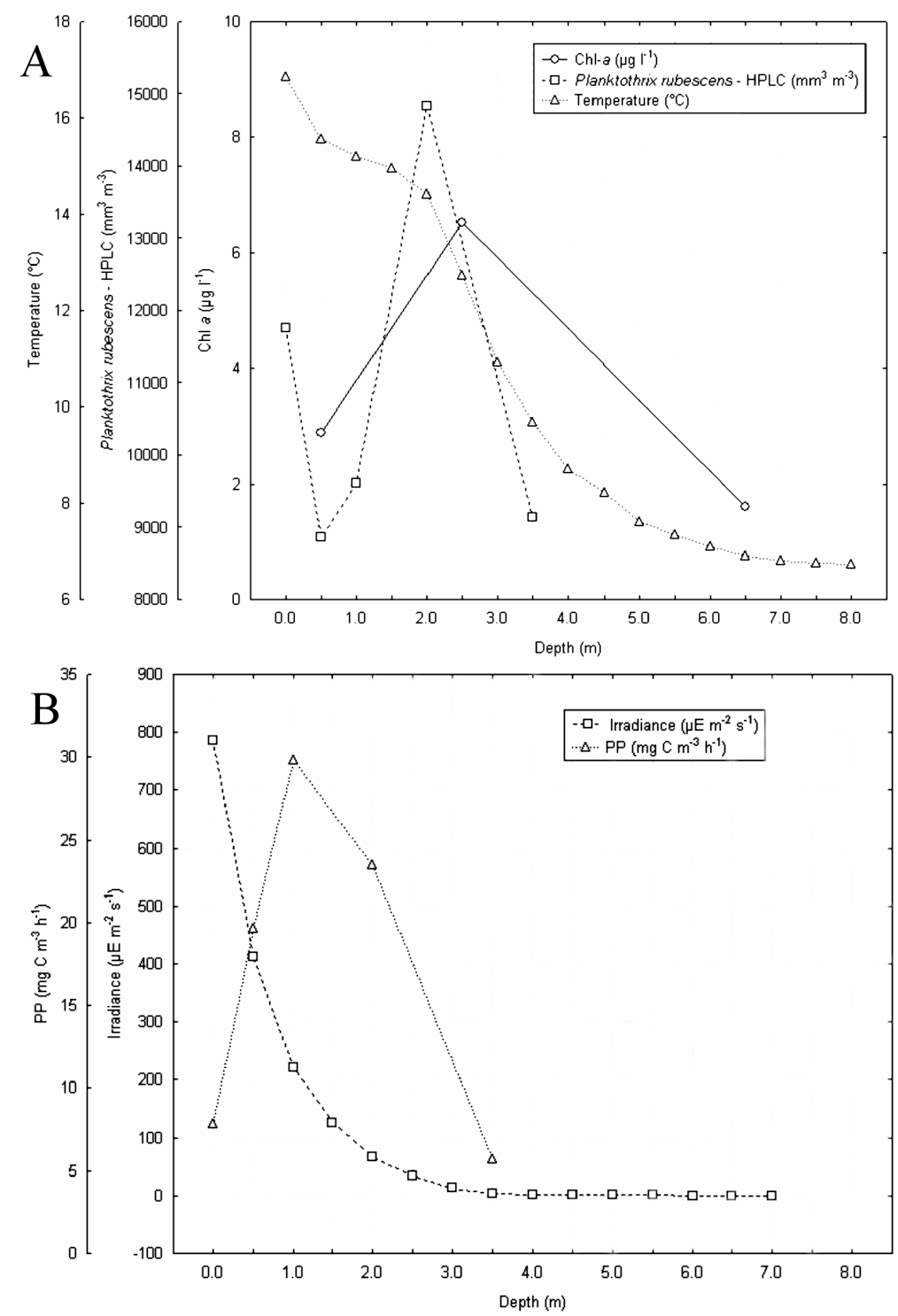

Fig. 9. (A) Vertical distribution of Planktothrix rubescens, temperature and chlorophyll- $a$; (B) Vertical distribution of primary production and light radiance.
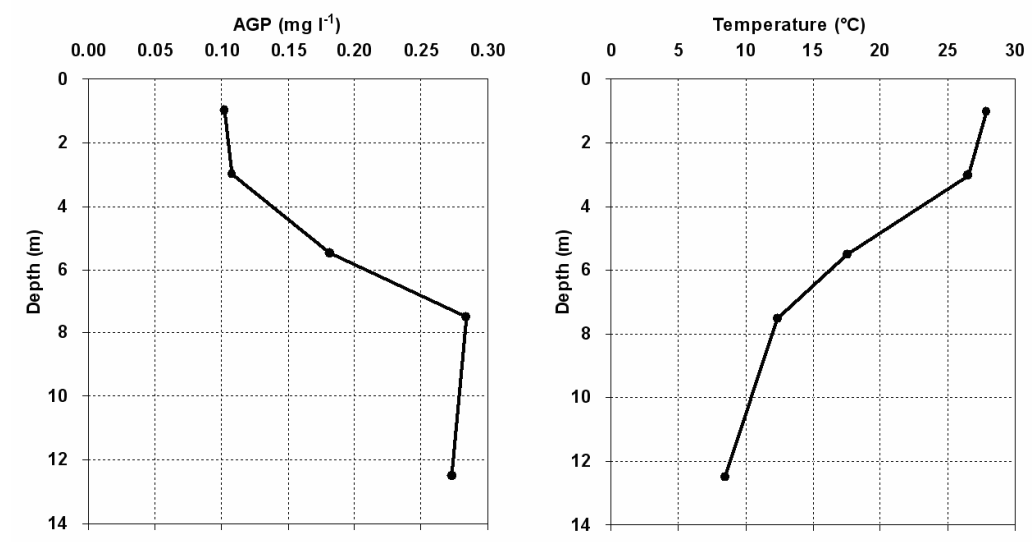

Fig. 10. Algal Growth Potential assay and profile temperature during the experiment. 
The capability of this species to overcome the winter with a conspicuous inoculum from the previous season has been documented by Walsby et al. (1998) for Lake Zürich and by Salmaso (2000) for Lake Garda. The autumnal inoculum gave $P$. rubescens an early competitive advantage in exploiting the resources available at the beginning of the growing season. For instance, the $\mathrm{P}_{-} \mathrm{PO}_{4}$ during winter overturn was highly concentrated and homogeneously distributed along the water column, allowing $P$. rubescens to increase its population, reaching the maximum at the end of April.

The overwhelming dominance of Planktothrix rubescens had only a short summer break, in concomitance with the development of Microcystis and Aphanothece. Our data do not allow to identify the process which mainly originated the $P$. rubescens crash: the most probable explanation point towards a sudden change in the light climate of the metalimnetic niche, which became too much illuminated, with irradiance intensities perhaps inhibiting the shade $P$. rubescens, as indicates the value of the $Z_{\mathrm{eu}} / \mathrm{Z}_{\mathrm{m}}$ ratio, increased by almost four times (from 1.2 at July, 15 to 4.3 at July, 29 ), thus overcoming the suitable range of 0.2-1.2 (Schreurs 1992). As a consequence, P. rubescens migrated downward, to depths between 8 and $15 \mathrm{~m}$, at the end of July. Until the end of August, the species maintained its deeper displacement. At least two processes could be responsible for this physical change: the first one is the epilimnetic nutrient depletion occurred during summer, which determined a reduction of the primary productivity in the upper layer and, consequently, an increase in both transparency and depth of the euphotic zone. The second process is dealing with the relationship between water column transparency and $P$. rubescens biomass: these two variables are mutually dependent, so that an increase in transparency led to a reduction in $P$. rubescens and a reduction in $P$. rubescens to an increase in transparency. The intense rainfall of July (see Fig. 3), cleaning up the surface waters, determined a deepening of the euphotic layer and an increase of transparency, which, due to the mutual dependence between $P$. rubescens biomass and transparency, gave rise to a positive feedback, which led the system to an abrupt crash (Scheffer et al. 1997). The decline of $P$. rubescens and its deepening left the upper water layers open to the colonization by other species: those tolerating high values of irradiance and taking advantage from water column stability, such as the coccoid Cyanoprokaryota, were the most favourite. Therefore, the coexistence of the two cyanobacteria types found between July and August, can be interpreted as an example of spatial and temporal separation of two different niches: the physical and chemical features of the water column separate a superficial niche characterized by intense light irradiance but limited by nutrients, and a deepest niche, where the nutrients concentration is higher and the environment is limited by the light intensity. The deepest niche is colonized by R-strategists organisms (Reynolds 1997), such as P. rubescens, well adapted to low light intensity, whereas the superficial niche is colonized by S-strategists organisms (e.g. Microcystis aeruginosa), well adapted to grow at the high light intensity of the surface waters. However, the impact of allocthonous climatic factors (the heavy rain of July), through an abrupt change of the physical conditions of the water column, also contributed to a temporal separation of the two niches, favouring the decline of Planktothrix rubescens and the increase of the Chroococcales.

The large dominance of Planktothrix rubescens during 2002 may appear in contrast with the recent improving of the trophic state of the lake; however, the phenomenon is quite common in the deep European lakes.

An increase in $P$. rubescens abundance, after a progressive nutrient load reduction, has been described in different large and deep sub-alpine lakes, such as Lake Constance (Gaedke 1998), Lake Geneva (Anneville et al. 2002) Lake Zürich (Gammeter \& Zimmermann 2000) and Lake Baldegg (Buergi \& Stadelmann 2000) where the reduction of the epilimnetic phosphorus concentration, as a consequence of the trophic improvement, determined a summer decrease of the primary productivity. The consequent increase in transparency allowed the metalimnion to be included into the euphotic zone, favouring those Rstrategist species, such as Planktothrix rubescens, able to grow under dim light, exploiting the high nutrient availability (Reynolds 1997). Despite the lack of limnological information between 1994 and 2001, our data let us hypothesise, for Lake Pusiano, a similar evolution of phytoplankton assemblages. The dominance of Planktothrix rubescens in 2002, the stable thermal gradient during summer, the strong epilimnetic phosphorus limitation, joined to a higher phosphorus bioavailability within the metalimnion, support this view. The metalimnetic chlorophyll maximum due to Planktothrix rubescens, characterizing Lake Pusiano during our study, is commonly recorded in the mesotrophic deep lakes of the subalpine district, not only in the large lakes above mentioned, but also in lakes of smaller volume and depth (e.g. Teubner et al. 2003): apart the trophic condition, the critical factor for the establishment of a consistent $P$. rubescens population is probably the length of the water column, which must be deep enough for the formation of a stable thermocline during summer. This feature makes Lake Pusiano not so different from the deep European subalpine lakes, in terms of both thermal structure and ecological patterns, despite its relatively small size.

On the other side, the abrupt disappearance of $P$. rubescens between 2002 and 2003 (occurred after an intense autumnal flood), points out the strong 
relationship between the biotic responses of the lake and the input from the catchment, as well as the sensitivity of this environment to hydrological stressors, suggesting an ecological resilience (Holling 1973) intermediate between shallow/small and deep/large lakes.

Current and future research are and will be addressed to clarify the relationships linking the hydrology of the catchment with the biocoenosis variability, coupling seasonal and intensive measurements as well as lake and catchment models (Salerno et al. 2004). The basic idea is to study the lake-catchment system as a whole, where the ecological response is strictly related to the meteorological input as well as to the hydrological pulse and the nutrient load coming from the catchment. In fact, the seasonal meteorological forcing can induce biomass changes or shifts of the succession pattern: however, both events are strictly related to the trophic condition of the lake, because of the pool of the favourite species that may develop is determined by the local environmental conditions, as well demonstrated by Anneville et al. (2004). Therefore, an integrated study of the lake and its catchment could give useful information to interpret both the seasonal and yearly changes of the phytoplankton assemblages, in particular in a lake ecosystem, such as Lake Pusiano, undergoing a trophic evolution.

\section{REFERENCES}

A.P.H.A., A.W.W.A. \& W.E.F. 1995. Standard methods for the examination of water, sewage and industrial wastes. Amer. Publ. Health Ass., New York: 522 pp.

Ade, P. \& E. Funari. 2000. Valutazione del rischio sanitario associato alle fioriture di cianobatteri. Atti Workshop "Aspetti sanitari della problematica dei cianobatteri nelle acque superficiali italiane”, Roma, 16-17 dicembre 1999. Rapporti ISTISAN 00/30: 33-51.

Anneville, O., S. Souissi, S. Gammeter \& D. Straile. 2004. Seasonal and inter-annual scales of variability in phytoplankton assemblages: comparison of phytoplankton dynamics in three peri-alpine lakes over a period of 28 years. Freshwat. Biol., 49(1): 98-115.

Anneville, O., S. Souissi, F. Ibanez, V. Ginot, J.C. Druart \& N. Angeli. 2002. Temporal mapping of phytoplankton assemblages in Lake Geneva: annual and interannual changes in their patterns succession. Limnol. Oceanogr., 47(5): 1355-1366.

Balestrini, R., L. Galli \& G. Tartari. 2000. Wet and dry atmospheric deposition at prealpine and alpine sites in Northern Italy. Atmospheric Environment, 34: 1455-1470.

Bonomi, G., C. Bonacina, \& I. Ferrari. 1967. Caratteristiche chimiche, plancton e benton nel quadro evolutivo recente dei laghi briantei. Mem. Ist. ital. Idrobiol., 21: 241-287.

Bray, J.R. \& J.T. Curtis. 1957. An ordination of the upland forest communities of Southern Wisconsin. Ecol. Monogr., 27: 325-349.

Buergi, H.R. \& P. Stadelmann. 2000. Change of phytoplankton diversity during long-term restoration of Lake Baldegg (Switzerland). Verh. int. Ver. Limnol., 27: 574-581.

Camusso, M. \& S. Polesello. 2000a. Determinazione di anioni (cloruro, nitrato, solfato, bromuro, floruro, fosfato e nitrito) mediante cromatografia ionica. Notiziario dei metodi analitici IRSA-CNR, 2: 1-8.
Camusso, M. \& S. Polesello. 2000b. Determinazione di cationi (sodio, ammonio, potassio, magnesio e calcio) mediante cromatografia ionica. Notiziario dei metodi analitici IRSACNR, 2: 8-14.

Chiaudani, G. \& M. Vighi. 1974. The N:P ratio and tests with Selenastrum to predict eutrophication in lakes. Wat. Res., 8: 1063-1069.

Chiaudani, G. \& G. Premazzi. 1992. I laghi briantei. Situazione trofica e soluzioni scientifiche per il risanamento. EUR 14548 IT: 211 pp.

Chorus, I. \& J. Bartram. 1999. Toxic Cyanobacterial in water. A guide to their public health consequence, monitoring and management. E\&FN SPON, London: $416 \mathrm{pp}$.

Danish Standard Association. 1982. Water Quality-Incubator method for determining the carbon assimilation by plankton algae using ${ }^{14} \mathrm{C}$ technique. Dansk Standard, DS/R: 293.

de Bernardi, R., G. Giussani, P. Guilizzoni \& R. Mosello. 1985. Indagine conoscitiva per una caratterizzazione limnologica dei Piccoli Laghi Lombardi. Documenta Ist. ital. Idrobiol., 8: $205 \mathrm{pp}$.

EPA (Environmental Protection Agency). 1978. The Selenastrum capricornutum Printz algal assay bottle test. Experimental design, application and data interpretation protocol. EPA-600/9-78-018. Corvallis (Ed.), Oregon.

Ettl, H. 1978. Sübwasserflora von Mitteleuropa. Xantophyceae. A. Pascher (Ed.), 3: 530 pp.

Feuillade, J. 1994. The cyanobacterium (blue-green alga) Oscillatoria rubescens D.C. Ach. Hydrobiol. Beih., 41: 7793.

Feuillade, M. \& A. Davies. 1994. Seasonal variation and longterm trends in phytoplankton pigments. Arch. Hydrobiol. Beih., 41: 95-111.

Frère, I.M. 1938. Flore desmidiale de la region de Montréal. Laprairie, Canada: $547 \mathrm{pp}$.

Gaedke, U. 1998. Functional and taxonomical properties of the phytoplankton community of large and deep Lake Constance: interannual variability and response to reoligotrophication (1979-1993). Arch. Hydrobiol. Spec. Issues Adv. Limnol., 53: 119-141.

Gaggino, G.F. \& E. Cappelletti. 1984. Catasto dei laghi italiani. Quaderni IRSA, 72: $974 \mathrm{pp}$

Gammeter, S. \& U. Zimmermann. 2000. Changes in phytoplankton productivity and composition during reoligotrophication in two Swiss lakes. Verh. int. Ver. Limnol., 27: 2190-2193.

Garibaldi, L., F. Buzzi, G. Morabito, N. Salmaso \& M. Simona. 2000. I cianobatteri fitoplanctonici dei laghi profondi dell'Italia Settentrionale. Atti Workshop "Aspetti sanitari della problematica dei cianobatteri nelle acque superficiali italiane", Roma, 16-17 dicembre 1999. Rapporti ISTISAN 00/30: 117-135.

Geitler, L. 1932. Cyanophyceae. In: R. Kolkwitz (Ed.). Die Algen. L. Robenhorst. Kryptogamen Flora von Deutschland un der Schweiz. Vol. 14. Akademische Verlagsgesellschaft, Leipzig: 1196 pp.

Gerletti, M. \& R. Marchetti. 1977. Indagini sui laghi della Brianza. Quaderni Istituto Ricerca Sulle Acque, 19: 358 pp.

Holling, C.S. 1973. Resilience and stability of ecological systems. Annual Review of Ecology and Systematics, 4: 123.

Jeffrey, S.W., R.F.C. Mantoura \& S.W. Wright. 1997. Phytoplankton pigments in oceanography. UNESCO, Imprimerie Jouve, Paris: $661 \mathrm{pp}$.

Klemer, A.R. 1976. The vertical distribution of Oscillatoria agardhii var. isothrix. Arch. Hydrobiol., 78: 343-362.

Komarek, J. \& K. Anagnostidis. 1999. Cyanoprokaryota. A. Pascher, 19: 548 pp. 
Konopka, A. 1980. Physiological changes within a metalimnetic layer of Oscillatoria rubescens. Applied and Enviromental Microbiology, 40(3): 681-684.

Krammer, K. \& H. Lange-Bertalot. 1986. Subwasserflora von Mitteleuropa. Bacillariophyceae. Vol. 1. A. Pascher: 876 pp.

Krammer, K. \& H. Lange-Bertalot. 1988. Subwasserflora von Mitteleuropa. Bacillariophyceae. Vol. 2. A. Pascher: 595 pp.

Krammer, K. \& H. Lange-Bertalot. 1991a. Subwasserflora von Mitteleuropa. Bacillariophyceae. Vol. 3. A. Pascher: $576 \mathrm{pp}$.

Krammer, K. \& H. Lange-Bertalot. 1991b. Subwasserflora von Mitteleuropa. Bacillariophyceae. Vol. 4. A. Pascher: $437 \mathrm{pp}$.

Krammer, K. \& H. Lange-Bertalot. 2000. Subwasserflora von Mitteleuropa. Bacillariophyceae. Vol. 5. A. Pascher: 311 pp.

Kromkamp, J.C. \& A.E. Walsby. 1990. A computer model of Buoyancy and vertical migration in cyanobacterial. $J$. Plankton Res., 12: 161-183.

Kurmayer, R. \& F. Jeüttner. 1999. Strategies for the coexistence of zooplankton with the toxic cyanobacterium Planktothrix rubescens in Lake Zürich. J. Plankton Res., 21: 659-683.

Marchetti, R. 1987. L'eutrofizzazione: un processo degenerativo delle acque. Collana scientifica Franco Angeli, Milano: 315 pp.

Micheletti, S., F. Schanz, \& A.E. Walsby. 1998. The daily integral of photosynthesis by Planktothrix rubescens during summer stratification and autumnal mixing in Lake Zurich. New Phytol., 193: 233-246.

O.E.C.D. 1982. Eutrophication of waters. Monitoring, assessment and control. O.E.C.D., Paris: 164 pp.

Platt, T. 1971. The annual production of phytoplankton in St. Margaret's Bay, Nova Scotia. J. Cons. Explor. Mer., 33(3): 324-333.

Quattrin, B., L. Garibaldi, M. Prina \& G. Tartari. 1998. Evoluzione limnologica recente (1984-1996) del Lago di Pusiano. Acqua \& Aria, 5/98: 89-101.

Redfield, A.C. 1934. On the proportions of organic derivatives in seawater and their relation to the composition of plankton. In: R.J. Daniel (Ed.), James Johnston Memorial Volume. University Press of Liverpool, Liverpool: 176192.

Regione Lombardia. 1994. Carta Tecnica Regionale 1:10000. www.regione.lombardia.it

Reynolds, C.S. 1984. The ecology of freshwater phytoplankton. Cambridge University: $384 \mathrm{pp}$.

Reynolds, C.S. 1997. Vegetation processes in the pelagic: a model for ecosystem theory. Excellence in Ecology, 9: 1371.

Rott, E. 1981. Some results from phytoplankton counting intercalibrations. Schweiz. Z. Hydrol., 43(1): 34-62.

Salerno, F., J. Boguniewicz, E. Buraschi, E. Vuillermoz. \& G. Tartari. 2004. Application of a semi-distributed model to a complex hydrogeological watershed. Proc. ECOGEOWATER EuroWorkshop "GI for International River Basin Management", Budapest (Hungary), June 3-5, 2004. (Published on: http://www.gisig.it/eco\%2Dgeowater/ VirtualPConference/first.asp).

Salmaso, N. 2000. Factors affecting the seasonality and distribution of cyanobacteria and chlorophytes: a case study from the large lakes south of the Alps, with special reference to Lake Garda. Hydrobiologia, 438: 43-63.
Scaglia, E. 1986. L'evoluzione trofica del lago di Pusiano negli ultimi 15 anni. Tesi di Laurea. Università degli Studi, Milano: $110 \mathrm{pp}$.

Scheffer, M., S. Rinaldi, A. Gragnani, L.R. Mur \& E.H. Van Nes. 1997. On the dominance of filamentous cyanobacteria in shallow, turbid lakes. Ecology, 78(1): 272-282.

Schmitt, J. \& J.H. Olive. 1980. Interacting effects of light, temperature, and nutrients on C-14 uptake of Oscillatoria rubescens de Candolle. Hydrobiologia, 70: 51-56.

Schreurs, H. 1992. Cyanobacterial dominance. Relations to eutrophication and lake morphology. Tesi di Dottorato. Università di Amsterdam: $198 \mathrm{pp}$.

Shannon, C.E. \& W. Weaver. 1949. The Mathematical Theory of Communication. University of Illinois Press, Urbana.

Sicko-Goad, L., E.F. Stoermer \& B.G. Laudewski. 1977. A morphometric method for correcting phytoplankton cell volume estimates. Protoplasma, 93: 147-163.

Starmach, K. 1966. Flora slodkowodna Polski. Cyanophyta, Glaucophyta. Vol. 2. Państwowe Wydawnictwo Naukowe, Warszawa: 806 pp.

Starmach, K. 1974. Flora slodkowodna Polski. Cryptophyceae, Dinophyceae, Raphidophyceae. Vol. 4. Państwowe Wydawnictwo Naukowe, Warszawa: 519 pp.

Starmach, K. 1980. Flora slodkowodna Polski. Chrysophyceae. Vol. 5. Państwowe Wydawnictwo Naukowe, Warszawa: $774 \mathrm{pp}$.

Sukenik, A., R. Eshkol, A. Livne \& O. Hadas. 2002. Inhibition of growth and photosynthesis of the dinoflagellate Peridinium gatunense by Microcystis sp. (cyanobacteria): a novel allelopathic mechanism. Limnol. Oceanogr., 47: 1656-1663.

Tartari, G., A. Marchetto \& D. Copetti. 2000. Qualità delle acque lacustri della Lombardia alle soglie del 2000. Fondazione Lombardia per l'Ambiente: 226 pp.

Teubner, K., M. Tolotti, S. Greisberger, H. Morscheid, M.T. Dokulil \& H. Morscheid. 2003. Steady state phytoplankton in a deep pre-alpine lake: species and pigments of epilimnetic versus metalimnetic assemblages. Hydrobiologia, 502: 49-64.

Trevisan, R. 1978. Nota sull'uso dei volumi cellulari algali per la stima della biomassa. Riv. Idrobiol., 17(3): 350-357.

Valderrama, J.C. 1977. Methods used by the Hydrographic Department of the National Board of Fisheries. Goteborg, Sweden: $538 \mathrm{pp}$.

Valderrama, J.C. 1981. The simultaneous analysis of total phosphorus in natural waters. Marine Chemistry, 10: 109122.

Vollenweider, R.A. 1965. Materiali ed idee per una idrochimica delle acque insubriche. Mem. Ist. ital. Idrobiol., 19: 213-286.

Walsby, A.E. \& A.R. Klemer. 1974. The role of gas vacuoles in the microstratification of a population of Oscillatoria agardhii var. isothrix in Deming Lake (Minnesota). Arch. Hydrobiol., 74: 375-392.

Walsby, A.E., A. Avery \& F. Schanz. 1998. The critical pressures of gas vesicles in Planktothrix rubescens in relation to the depth of winter mixing in Lake Zurich (Switzerlaand). J. Plankton Res., 20(7): 1357-1375.

Walsby, A.E., Z. Dubinsky, J.C. Kromkamp, C. Lehamann \& F. Schanz. 2001. The effects of diel changes in photosynthetic coefficients and depth of Planktothrix rubescens on daily integral of photosynthesis in Lake Zürich. Aquat. Sci., 63: 326-349.

Webster, K.E. \& H. Peters. 1978. Some size-dependent inhibitions of larger cladoceran filters in filamentous suspensions. Limnol. Oceanogr., 23: 1238-1245. 